\title{
The brine shrimp Artemia (Crustacea; Anostraca): a model organism to evaluate management policies in aquatic resources
}

\author{
El camarón de salmuera Artemia (Crustacea, Anostraca): organismo modelo para evaluar \\ políticas de manejo de recursos acuáticos \\ PATRICIO DE LOS RÍOS ${ }^{1} \&$ GONZALO GAJARDO ${ }^{2 *}$ \\ ${ }^{1}$ Universidad Austral de Chile, Instituto de Ecología y Evolución, Casilla 567, Valdivia, Chile; \\ e-mail: patatorios@terra.cl \\ ${ }^{2}$ Universidad de los Lagos, Laboratorio de Genética \& Acuicultura, Casilla 933, Osorno, Chile; \\ ${ }^{*}$ Corresponding author: e-mail: ggajardo@ulagos.cl
}

Some organisms not only play an essential role as models for scientific development, but also help to bridge the gap between science and what society expects from it when some aspect of such organisms has an immediate application to satisfy evident human needs. The brine shrimp Artemia is a paradigmatic model in this regard. The striking biological characteristics of this organism have been successfully applied to the development of marine fish and crustacean farming (Lavens \& Sorgeloos 2000). Artemia exhibits a unique ability to live and reproduce in waters of high salinity $(0.4-3.4 \mathrm{M})$ and variable ionic conditions. Not surprisingly, members of the genus are referred as the extremophiles of the biological world, e.g., the encysted gastrula embryo (cyst) is the most resistant of all animal life history stages, while the motile stages (nauplii and adults) are among the best osmoregulators in the animal kingdom (Clegg \& Trotman 2002). These and other amazing life history traits, including an easy handling under laboratory conditions (De Los Rios 2001), makes Artemia a model organism of choice for many basic disciplines, particularly for studies on adaptation and speciation (Gajardo et al. 2002).

As any exploited organism, Artemia often confronts the interests of users and those seeking to protect the environment and local genetic resources (Gajardo \& Beardmore 2001). Chile is potentially not an exception, and the objective of this letter is to draw the attention on the importance to protect local Artemia resources and their habitat.

Hypersaline environments are ancient and very unique ecological settings, distributed, though not exclusively, in tropical and subtropical areas. The salty lakes and lagoons scattered over the Salar de Atacama are considered quite unique since they exhibit a combination of biotic and abiotic conditions that have caused complex speciation patterns in Artemia (Gajardo et al. 1998, 2002). Accordingly, some local Artemia populations are genetically unique in relation to regional or global biodiversity. Two out of seven bisexual Artemia species are found in Chile, namely $A$. franciscana (Kellog 1906) and A. persimilis (Piccinelli \& Prosdocini 1968). The former, the dominant species in the Americas, is distributed in north and central Chile, between 18-30 ${ }^{\circ} \mathrm{S}$ (Gajardo et al. 1998). Genetic analyses at different levels (e.g., DNA, proteincoding loci and karyological traits) (Gajardo \& Beardmore 2001, Gajardo et al. 2001, 2002) have revealed high genetic divergence between local populations and reference samples of $A$. franciscana, some of which is linked to traits relevant to aquaculture (e.g., ovoviparity; cyst diameter and naupliar size).

Both the autochthonous Artemia and their habitat can be threatened by ongoing mining activities in "salares" of the Atacama desert, which are rich mineral deposits. But foreseen risks are likely to come as marine fish farming, which typically uses Artemia nauplii as live food for fish larval stages, continuous to grow worldwide, including Chile. A significant proportion of Artemia cysts traded in world markets used to be harvested from Great Salt Lake (GSL) in Utah, USA. However, harvest unpredictability and cyst shortage (less than 2,500 tons are from GSL) has urged producers to explore new sites around the world. Local Artemia resources in Chile might be of high priority, provided they meet international quality standards and turn out more cost-effective in relation to what the world market offers. Harvesting pressure on sites in Chile could selectively deplete certain genotypes, whilst translocation or introduction of new and exotic species or populations (e.g., parthenogenetic types) that can out compete local ones, could 
become common practices. This is actually happening with the introduction of $A$. franciscana, the most widely used species for aquaculture, in Europe and Asia where marine fish farming has boomed. To a certain extent, this represents the introduction of an exotic species, a common practice in global and Chilean aquaculture as well (Gajardo \& Laikre 2003).

Conflicts between interested parties are difficult to resolve with the few systematic studies at hand on the various aspects of biology and ecology of Artemia species. Such conflicts often turn out in favor of those profiting on natural resources and there are many examples of native species driven almost to extinction by over-harvest before the minimum information required for wise management decision has been obtained (Lavens \& Sorgeloos 2000). Artemia offers advantages as a model for risk assessment and to evaluate management decisions in exploited resources that could be extrapolated to other species, including exotics. One is the availability of a genetic database or baseline and molecular tools for further monitoring gene pools in space and time. The opportunity to establish gene banks from cysts collected from different sites assures population persistence while relevant management information is produced. Considering the relatively simple structure of hypersaline habitats, the different aspects needed to evaluate population/species persistence in nature can be modeled under laboratory conditions. Likewise, the genetic characteristics and population dynamics of a successful colonizer, such as A. franciscana, modeled for a particular set of environmental conditions, could help to predict its ability to out compete other species. Such testing is valuable to predict the fate of exotic species in new environments. There are, however, some potential problems that need to be solved before the above benefits can be realized. Artemia is a small crustacean species that lives in an exotic setting far beyond the eyes of the common public. Besides a reduced number of Chilean scientists and aquaculture people who use these organisms as animal food, the scientific and economic importance of Artemia is not well appreciated. Yet the relevant literature for managers and users is available in the form of peer-reviewed literature. The project "Artemia Biodiversity, current global resources and their sustainable exploitation", a EU-funded concerted action, which has supported this reflection on Chilean Artemia resources, is aimed at the preservation and sustainable exploitation of Artemia biodiversity. The project will issue guidelines for authorities in order to protect biodiversity and to avert overexploitation and extinction of Artemia strains.

\section{LITERATURE CITED}

CLEGG JS \& CAN TROTMAN (2002) Physiological and biochemical aspects of Artemia ecology. In: Abatzopoulos TH, JA Beardmore, JS Clegg \& P Sorgeloos (eds) Artemia: basic and applied biology: 129-170. Kluwer Academic Publishers, Dordrecht, The Netherlands.

DE LOS RÍOS P (2001) Crecimiento en poblaciones de Artemia franciscana y A. persimilis (Crustacea, Anostraca) en condiciones controladas. Revista de Biología Tropical 49: 629-634.

DHONT J \& P SORGELOOS (2002) Applications of Artemia. In: Abatzopoulos TH, JA Beardmore, JS Clegg \& P Sorgeloos (eds) Artemia: basic and applied biology: 251-277. Kluwer Academic Publishers, Dordrecht, The Netherlands.

GAJARDO G \& L LAIKRE (2003) Chilean aquaculture boom is based on exotic salmon resources: a case of conservation paradox. Conservation Biology 17: 1173 .

GAJARDO G, TJ ABATZOUPOULOS, I KAPPAS \& JA BEARDMORE (2002) Evolution and speciation. In: Abatzopoulos TJ, JA Beardmore, J Clegg \& $\mathrm{P}$ Sorgeloos (eds) Artemia: basic and applied biology: 225-250. Kluwer Academic Publishers, Dordrecht, The Netherlands.

GAJARDO GM \& JA BEARDMORE (2001) Coadaptation: lessons from the brine shrimp Artemia, "the aquatic Drosophila" (Crustacea, Anostraca). Revista Chilena de Historia Natural 74: 65-72.

GAJARDO G, N COLIHUEQUE, M PARRAGUEZ \& P SORGELOOS (1998) International study on Artemia. VIII. Morphologic differentiation and reproductive isolation of Artemia populations from South America. International Journal of Salt Lake Research 7: 133-151.

LAVENS P \& P SORGELOOS (2000) The history, present, status and prospects of the availability of Artemia cysts for aquaculture. Aquaculture 181: 397-403. 